\title{
BIOLOGICAL CONVERSION OF NARBONOLIDE TO PICROMYCIN
}

\author{
Isao Maezawa, Tetsuo Hori, Akio Kinumaki \\ and MAKoTo SUZUKI \\ Microbial Chemistry Research Laboratory, Tanabe Seiyaku Co., Ltd., \\ Toda, Saitama, Japan \\ (Received for publication September 21, 1973)
}

\begin{abstract}
The macrolide antibiotic, picromycin, was found to be synthesized from narbonolide by the following two metabolic pathways: (A) Narbonolide (I) $\rightarrow$ narbomycin (II) $\rightarrow$ picromycin (III). (B) Narbonolide (I) $\rightarrow$ picronolide (IV) $\rightarrow$ picromycin (III). In path (A) glycosidation at $\mathrm{C}-5$ with desosamine preceded hydroxylation at C-12, while in path (B) the reverse is true.
\end{abstract}

Narbomycin (II) and picromycin (III) are 14-membered macrolide antibiotics possessing a desosamine moiety at the C-5 hydroxyl group and differentiated from each other by the absence or the presence of a hydroxyl group at the $\mathrm{C}-12$ position. The aglycones of narbomycin and picromycin were called narbonolide ${ }^{3)}(\mathbf{I})$ and picronolide $^{1)}$ (IV), respectively. Biogenetically, these two substances seemed to be constituted of six propionates and one acetate judging from a similarity of the structure with narbomycin ${ }^{22}$.

Recently we succeeded in isolating two new intermediates (I and IV) and by using these substances in feeding experiments with washed cells, we ascertained that they played a role as important intermediates leading to picromycin ${ }^{1,3,4)}$.

As reported previously ${ }^{3,4)}$ and as shown in Fig. 1, in experiment using washed cells of Streptomyces narbonensis ISP-5016 which produced narbomycin as a sole product, the antibiotic activity in a cell suspension was highly enhanced in the presence of narbonolide. Fifty $\mathrm{mg}$ of narbonolide added to one liter of the washed cell suspension completely disappeared in 6 hours along with the production of an antibiotic. The antibiotic was isolated by ethyl acetate extraction followed by silica gel preparative thin-layer chromatography and then identified as narbomycin.

Moreover, when narbonolide was added to the cell suspension of Streptomyces zaomyceticus MCRL-0405 which produced picromycin as a main product, the antibiotic activity of the cell suspension was increased as in the case of $S$. narbonensis, but the presence of narbonolide was not detected in the suspension (Fig. 2). From these preliminary experiments, it was postulated that narbomycin might be converted by $S$. zaomyceticus into picromycin. When

Fig. 1. Transformation of narbonolide to an antibiotic (narbomycin) by the washed cell suspension of $S$. narbonensis ISP-5016

Narbonolide was added to the cell suspension of $S$. narbonensis ISP-5016 cultured in the basal medium, and the mixture was incubated on a shaker and sampled at an indicated time. The reaction conditions:

Narbonolide concentration; $\quad 50 \mu \mathrm{g} / \mathrm{ml}$

Temperature; $\quad 27^{\circ} \mathrm{C}$

Buffer solution; Tris-HCl buffer, $\mathrm{pH} 8.5,0.02 \mathrm{M}$

Culture ages of cell; 20 hours

Cell concentration; $4.8 \mathrm{mg} / \mathrm{ml}$

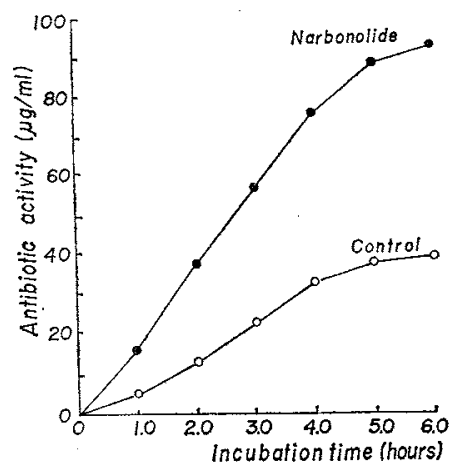


Fig. 2. Transformation of narbonolide to antibiotics (picromycin as a main product) by the washed cell suspension of S. zaomyceticus MCRL-0405. The reaction conditions:

Narbonolide concentration; $\quad 50 \mu \mathrm{g} / \mathrm{ml}$ Temperature; $\quad 27^{\circ} \mathrm{C}$ Buffer solution; Tris- $\mathrm{HCl}$ buffer, pH 8.5, $0.02 \mathrm{M}$

Culture ages of cell; 20 hours in basal medium

Cell concentration; $4.2 \mathrm{mg} / \mathrm{ml}$ (dry weight)

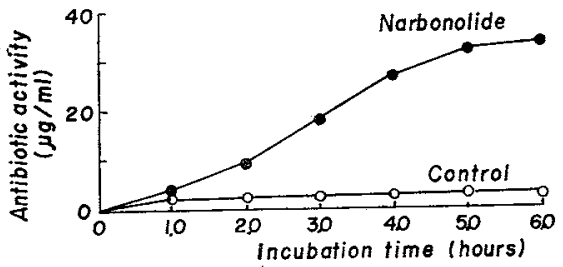

$50 \mathrm{mg}$ of narbomycin was addded to the cell suspension of this Streptomycete, most of the added narbomycin disappeared in 3 hours, and an antibiotic, which is distinct from narbomycin by thin-layer chromatography (silica gel, $\mathrm{CHCl}_{3}-\mathrm{MeOH}-\mathrm{AcOH}-\mathrm{H}_{2} \mathrm{O}, 79: 11: 8: 2$ ), was observed in the suspension. According to the procedure used in the narbomycin purification, the antibiotic was purified and identified as picromycin by direct comparison with authentic picromycin. Furthermore, as reported in the previous communication ${ }^{3)}$, labeled narbonolide, $\left[{ }^{2} \mathrm{H}\right]$ narbonolide $\left(69 \%\left[{ }^{2} \mathrm{H}_{3}\right], 25 \%\left[{ }^{2} \mathrm{H}_{2}\right]\right)$, was transformed into $\left[{ }^{2} \mathrm{H}\right]$ narbomycin $\left(23 \%\left[{ }^{2} \mathrm{H}_{1}\right], 6 \%\left[{ }^{2} \mathrm{H}_{2}\right]\right)$ by the washed cell suspension of $S$. narbonensis, and $\left[{ }^{2} \mathrm{H}\right]$ narbomycin $(41 \%$ $\left.\left[{ }^{2} \mathrm{H}_{1}\right], 14 \%\left[{ }^{2} \mathrm{H}_{2}\right]\right)$ was also converted into $\left[{ }^{2} \mathrm{H}\right]$ picromycin (13\% $\left[{ }^{2} \mathrm{H}_{1}\right], 4 \%\left[{ }^{2} \mathrm{H}_{2}\right]$ ) by the washed cell suspension of S. zaomyceticus.

These results obviously suggest that there is a precursor-product relationship between narbonolide, narbomycin and picromycin, that is, narbonolide is glycosidated with desosamine, and that the introduction of a hydroxyl group at $\mathrm{C}-12$ occurs after the glycosidation reaction.

On the other hand, as shown in previous report $t^{1)}$, picronolide was isolated from the culture broth of Streptomyces venezuelae MCRL-0376 which produced picromycin and narbomycin. This result suggested the possibility that picromycin could be transformed via picronolide from norbonolide. Therefore, narbonolide was incubated with a cell suspension of $S$. venezuelae grown in the sodium acetate $(0.04 \mathrm{M})$-added medium in which picronolide was accumulated.

When narbonolide was incubated with the cell suspension, a new transient product appeared, which was extracted with ethyl acetate and purified by silica gel preparative thin-layer chromatography (benzene-ethyl acetate, $1: 1$ ) and was identified as picronolide. For the accumulation of this compound, the cells grown in sodium acetate added medium was essential and the cells grown in the basal medium did not show the accumulation of this compound.

The mechanism of the accumulation of picronolide by the washed cells grown in the presence of sodium acetate is not apparent as yet, however, these cells are devoid of the ability to convert narbonolide to antibiotics ${ }^{1,4}$. Thus, the accumulation of picronolide results from the inability to convert narbonolide into antibiotics, when the cells were incubated with narbonolide.

$S$. narbonensis produced more antibiotic if picronolide was added to the cell suspension as shown in Fig. 3. Two antibiotics were observed and they were identified as narbomycin and picromycin, the main product being picromycin $(60 \%)$. These results showed that the main product, picromycin, was converted from picronolide and the minor product, narbomycin, was synthesized by the cell of S. narbonensis.

These observations also suggest that introduction of a hydroxyl function at C-12 could occur before the attachment of desosamine. Thus, the metabolic pathway involved in the biosynthesis of picromycin was elucidated by feeding experiments with washed cell suspension as summarized in Fig. 4.

Recently, a number of metabolic intermediates of erythromycin ${ }^{5,6}$ have been isolated and a new 
Fig. 3. Transformation of picronolide to an antibiotic (picromycin) by the washed cell suspension of $S$. narbonensis ISP-5016. The reaction conditions:

Picronolide concentration; $\quad 50 \mu \mathrm{g} / \mathrm{ml}$

Temperature; $\quad 27^{\circ} \mathrm{C}$

Buffer solution; Tris- $\mathrm{HCl}$ buffer, pH 8.5, $0.02 \mathrm{M}$

Culture ages of cell; 20 hours in the basal medium

Cell concentraticn; $5.5 \mathrm{mg} / \mathrm{ml}$ (dry weight)

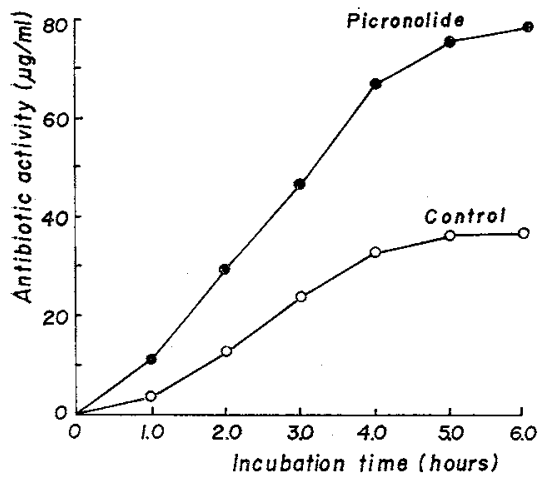

Fig. 4. Scheme proposed as a possible pathway for the final steps in picromycin biosynthesis<smiles>CCC(OC(=O)C(C)C(=O)C(C)C)C(C)C(C)CC(C)C(=O)/C=C/C(C)O</smiles>

Narbonolide (1)<smiles>CCC(OC(=O)C(C)C(=O)C(C)C(O)C(C)CC(C)C(=O)/C=C/C(C)(O)C(C)(C)O)C(C)C</smiles>

Picronolide (N)<smiles>CCC(OC(=O)C(C)C(=O)C(C)C(OC1CC(C)CC(C)O1)C(C)CC(C)C(=O)/C=C/C(C)C)C(C)C</smiles>

Narbomycin (II)

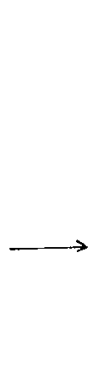

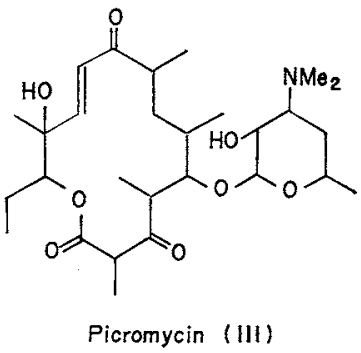

concept was introduced in the biosynthetic study of these antibiotics as reported by MARTIN et al." A possible metabolic pathway for erythromycin biosynthesis was shown as follows: Erythronolide-B (erythromycin aglycone) was glycosidated with mycarose, to form 3-O-mycarosyl-erythronolide-B, before introduction of a hydroxyl function at $\mathrm{C}-12$, and the substance can be metabolized to known erythromycins A, B and C via a speculated intermediate, 5-O-desosaminyl-3-O-mycarosylerythronolide-B, as a main pathway. Moreover, the other pathway in which insertion of a hydroxyl function at $\mathrm{C}-12$ occurred before the glycosidation reaction with desosamine was proposed as a secondary pathway. However, the metabolic intermediate on this pathway is not detected and experimental evidence is still lacking for the presence of such a metabolic pathway. The presence of this type of metabolic pathway became apparent in biosynthesis of picromycin.

\section{Experimental}

(1) Cultivation and Washed Cell Preparation

The cultivation of microorganisms was carried out at $27^{\circ} \mathrm{C}$ in $500-\mathrm{ml}$ Erlenmeyer flasks containing $100 \mathrm{ml}$ of the following medium on a rotatory shaker at $180 \mathrm{rpm}$. The fermentation medium (basal medium) used throughout the experiments consisted of glucose $10 \mathrm{~g}$, glycerol $10 \mathrm{~g}$, Polypepton $10 \mathrm{~g}$, meat extract $5 \mathrm{~g}, \mathrm{NaCl} 5 \mathrm{~g}, \mathrm{CaCl}_{2} 2 \mathrm{~g}$ and yeast extract $1 \mathrm{~g}$ in one liter ( $\mathrm{pH} 7.3$ ).

After growing for 20 hours in the basal medium, the cells were collected by centrifugation $(1,200 \mathrm{~g}, 10$ minutes $)$ washed three times with sterilized saline, and then suspended in a Tris-HCl buffer $(0.02 \mathrm{M}, \mathrm{pH} 8.5)$ at the cell density of approximate $5 \mathrm{mg}$ (dry weight) per $\mathrm{ml}$. The substrate, narbonolide, picronolide and narbomycin etc., were then added to the cell suspension to give final concentration of $50 \mu \mathrm{g} / \mathrm{ml}$.

Antibiotic production was assayed by the cup plate method using Bacillus subtilis PCI-219 as a test organism using picromycin as a reference standard. Amount of antibiotics were expressed in terms of picromycin equivalent. 


\section{(2) Conversion of Narbonolide to Narbomycin}

Washed cells of $S$. narbonensis ISP-5016 were prepared as described above. Fifty $\mathrm{mg}$ of narbonolide in one liter of Tris- $\mathrm{HCl}$ buffer ( $\mathrm{pH} 8.5,0.02 \mathrm{M}$ ) was incubated with washed cells (dry weight, $4.8 \mathrm{~g}$ ) at $27^{\circ} \mathrm{C}$ for 6 hours. After removal of cells, the filtrate was extracted twice with an equal volume of ethyl acetate. The extracts were combined, dried over anhydrous $\mathrm{Na}_{2} \mathrm{SO}_{4}$, and concentrated in vacuo to give an oily substance. The oily substance was chromatographed on a preparative silica gel thin-layer plate $\left(1.5 \mathrm{~mm}\right.$ thick, $\left.\mathrm{CHCl}_{3}-\mathrm{MeOH}-\mathrm{AcOH}-\mathrm{H}_{2} \mathrm{O}, 79: 11: 8: 2\right)$, and the desired compound II detected by an UV lamp was cut out and extracted with acetone, followed by removal of the solvent in vacuo to dryness. The eluate, by crystallization from ethyl acetate-nhexane, gave $27 \mathrm{mg}$ of a crystal of compound II, m.p. $112 \sim 114^{\circ} \mathrm{C}$; MW 509; IR $\nu_{\max }^{\text {nu jol }} \mathrm{cm}^{-1}: 3540$

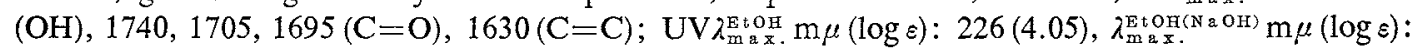
291 (4.10). No depression in mixed melting point determination and complete identity of IR spectrum with that of the authentic sample showed compound $\mathbf{I I}$ is narbomycin.

(3) Conversion of Narbomycin to Picromycin

Fifty $\mathrm{mg}$ of narbomycin in one liter of Tris-HCl buffer ( $\mathrm{pH} 8.5,0.02 \mathrm{M}$ ) was incubated with washed cells (dry weight $5.3 \mathrm{~g}$ ) of $S$. zaomyceticus MCRL-0 405 at $27^{\circ} \mathrm{C}$ for 3 hours. After removal of cells, the filtrate was extracted with an equal volume of ethyl acetate. The extract was dried over anhydrous $\mathrm{Na}_{2} \mathrm{SO}_{4}$, and concentrated in vacuo. The residual oily substance was chromatographed on a silica gel preparative thin-layer plate under the above conditions. The desired compound III detected by UV lamp was cut out and extracted with acetone. The eluate gave $17 \mathrm{mg}$ of compound III (crystalization from ethyl acetate- $n$-hexane), m.p. $167 \sim 169^{\circ} \mathrm{C}$; MW 525 ; IR $\nu_{\text {max. }}^{\text {matol. }}$

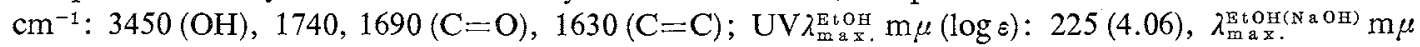
$(\log \varepsilon): 293(4.15)$. The IR spectrum of compound III was identical with that of the authentic picromycin.

\section{(4) Conversion of Narbonolide to Picronolide}

S. venezuelae MCRL-0376 was harvested in the medium containing $0.04 \mathrm{M}$ sodium acetate at $27^{\circ} \mathrm{C}$ for 30 hours and the washed cells were prepared as described above.

The washed cells (dry weight, 9.8 g) were suspended in 2 liters of Tris-HCl buffer (pH 8.5, $0.02 \mathrm{M})$ containing $100 \mathrm{mg}$ of narbonolide and incubated for 6 hours at $27^{\circ} \mathrm{C}$. After incubation, compound IV was extracted two times with an equal volume of ethyl acetate. The extracts were combined, and concentrated to syrup. The syrup was chromatographed on a preparative thin-layer plate (silica gel, $1.5 \mathrm{~mm}$, benzene-ethyl acetate, $1: 1$ ), and the desired compound IV detected by an UV lamp was cut out and extracted with acetone. The eluate gave $8 \mathrm{mg}$ of the crystals by crystalization from benzene- $n$-hexane, m.p. $141^{\circ} \mathrm{C}$; MW 368; IR $\nu_{\mathrm{max}}^{\text {nj jo. }} \mathrm{cm}^{-1}: 3500,3380(\mathrm{OH}), 1730,1700(\mathrm{C}=\mathrm{O})$, $1635(\mathrm{C}=\mathrm{C}) ; \mathrm{UV} \lambda_{\mathrm{max}}^{\mathrm{EtOH}} \mathrm{m} \mu(\log \varepsilon): 225(4.06), \lambda_{\mathrm{max}}^{\mathrm{EtOH} \text { (NOH) }} \mathrm{m} \mu(\log \varepsilon): 280(4.08)$. Complete identity of IR spectrum in nujol with that of authentic picronolide was observed.

\section{(5) Conversion of Picronolide to Picromycin}

Twenty $\mathrm{mg}$ of picronolide in $400 \mathrm{ml}$ of Tris-HCl buffer $(\mathrm{pH} 8.5,0.02 \mathrm{M}$ ) was incubated with washed cells (dry weight, $2.2 \mathrm{~g}$ ) of $S$. narbonensis ISP-5016, which produced narbomycin as a sole antibiotic in the culture, at $27^{\circ} \mathrm{C}$ for 6 hours. After incubation, the presence of two antibiotic substances was observed, and the antibiotic substances were purified by the procedure mentioned in the picromycin purification and they were identical with narbomycin and picromycin, respectively.

\section{Acknowledgement}

We thank Dr. T. OKudA, General Manager of our laboratory, for his interest and encouragement. We are also grateful to Dr. K. KOTERA and his colaborators of Analytical Center of this company for the instrumental analysis.

\section{References}

1) Maezawa, I.; A. Kinumaki \& M. Suzuki: Isolation and identification of picronolide, methynolide 
and neomethynolide produced by Streptomyces venezuelae MCRL-0376. J. Antibiotics, in press

2) VANeK, Z. \& J. Majer: Macrolide antibiotics, "Antibiotics" Vol. II, ed. by D. GotTLIEB and P. H. SHow, Springer-Verlag Berlin, pp. 154 188, 1967

3) Hori, T.; I. Maezawa, N. NAgahama \& M. Suzuki: Isolation and structure of narbonolide, narbomycin aglycone, from Streptomyces venezuelae and its biological transformation into picromycin via narbomycin. J. Chem. Soc., Chem. Commun. $1971: 304 \sim 305,1971$

4) Maezawa, M.; T. Hori \& M. Suzuki: Macrolide fermentation studies on Streptomyces venezuelae MCRL-0376. 1. Accumulation of narbonolide caused by the addition of organic acid. Agr. Biol. Chem., in press

5) TARDREw, P.L. \& N. A. NYMAN: Hypocholesterolemic agent M-850 and method of preparation. U.S. Patent, 3127315, Mar. 31, 1964 [C.A. $60: 16469,1964]$

6) Martin, J.R.; T.J. Perun \& R.L. Girolamic: Studies on the biosynthesis of the erythromycin. I. Isolation and structure of an intermediate glycoside, 3- $\alpha$-L-mycarosylerythronolide B. Biochemistry 5 : 2852 2856, 1966

7) Martin. J. R. \& A. W. Goldstein: Final steps in erythromycin biosynthesis. Proc. 6th Internat. Congr. Chemoth., Tokyo, Vol. 2, pp. 1112 1116, 1970 